\title{
Philosophy in Russell's letters to Alys
}

\section{by Carl Spadoni}

ONE OF THE most absorbing correspondences contained in the Russell Archives is that between Russell and his first wife, Alys Russell (nee Pearsall Smith, 1867-1951). This collection of letters has three sources. (1) There are the letters described in Feinberg's Catalogue and deposited at McMaster University in 1968 (Archives I) - these were originally in Russell's possession, presumably returned to him in July-August 1912 by Alys after their separation, and comprise approximately 137 letters from Russell and 28 from Alys. ${ }^{1}$ (2) Some 65 letters from Russell and one letter and a note from Alys arrived with Archives II in 1973, probably overlooked in the sorting of Archives I. A likely hypothesis is that (2) is equivalent to a bundle Alys returned to Russell in 1949. (3) The most recent acquisition, from Alys' grand-niece, Barbara Strachey Halpern, consists of three microfilm reels, approximately 3,400 exposures, about 450 letters from Russell and 600 from Alys. Some of the letters from (1) have already been printed in part or in whole in the first and third volumes of Russell's Autobiography. ${ }^{2}$ (1) and (2) were employed by Clark in his detailed reconstruction of Russell's life. ${ }^{3}$ Hitherto (3) has not been available for public scrutiny. Mrs. Halpern has drawn from (3)

' Barry Feinberg (ed.), A Detailed Catalogue of the Archives of Bertrand Russell (London: Continuum 1, 1967), pp. 54-55. The fact that Russell received these letters from Alys is substantiated by a letter written by Russell to Lady Ottoline Morrell (no. 529). I use the expression, "the Alys letters", to refer to Russell's letters to Alys.

${ }^{2}$ The Autobiography of Bertrand Russell, 1872-1914 (London: Allen and Unwin, 1967)), pp. 95-108. The Autobiography of Bertrand Russell, 1944-1967 (London: Allen and Unwin, 1969), pp. 46-52. The third volume of Russell's Autobiography contains Alys' letters after their reconciliation in 1949; Mrs. Halpern has recently located Russell's side of the correspondence for this period, amounting to ten letters.

${ }^{3}$ Ronald W. Clark, The Life of Bertrand Russell (London: Cape/Weidenfeld and Nicolson, 1975), especially chapters 2-3. 
along with other original source material in her possession and intends to complete a composite biography of the notable women of her family tree. ${ }^{4}$ The task of assessing these letters in terms of Russell's relationship with his first wife, the circumstances of their initial love for each other and the reasons for the failure of their marriage, I do not propose to undertake here. Even though he did not have access to all of the correspondence, Clark has already covered this territory and no doubt others will attempt to re-interpret the narrative. In discussing the Alys letters, my main aim, in contrast, will be rather prosaic: namely, to examine their philosophical content. In the same way in which Russell's letters to Lady Ottoline Morrell tell us about his philosophical development during that period of time-for example, the changes in his theory of judgment and his stormy relationship with Wittgenstein-Russell's letters to Alys reveal a fair amount about his earlier philosophy, especially his introduction to the study of philosophy in 1893-94. The correspondence does not tell a complete story, but nevertheless it illuminates areas hitherto unknown and obscured. My presentation of this material will be selective due to the vast number of letters.

Russell's first extant letter to Alys is dated 21 June 1893, approximately four years after their first meeting in the summer of 1889 at Friday's Hill. He had finished his Mathematical Tripos at Cambridge some weeks before, and having been frustrated by the makeshift practices of current mathematical technique, he had enthusiastically decided to take up philosophy instead. In that first letter, he remarked that he wanted to see Alys but was unable to do so, "one of the cases where enlightened self-interest and univeralistic Hedonism part company". Hedonism (or utilitarianism) is the ethical doctrine that an action ought to be performed if and only if it maximizes the pleasure or happiness of the persons affected thereby. Russell had accepted such a position in his adolescent notebook, the "Greek Exercises". However, when he first met J. McT. Ellis McTaggart, Cambridge's promising young metaphysician, in October 1890, McTaggart had referred to the doctrine as "a somewhat dry creed".5 For some time, it would seem, Russell retained his utilitarian outlook against McTaggart's onslaught, but by 26 February 1894 he wrote to Alys saying that he had "revolted from pure Hedonism which has annoyed [Henry] Sidgwick". "Old Sidg", nicknamed as such by Cambridge undergraduates, was "the last

${ }^{4}$ See Valerie Green, "Why Barbara Halpern Keeps Lytton Strachey on the Sofa", Oxford Mail, 22 February 1978.

s "Reminiscences of McTaggart", Trinity Magazine, Easter Term 1948, p. I. surviving representative of the Utilitarians". ${ }^{6}$ Although Russell judged him to be "not quite in the first rank", his meta-ethical views profoundly influenced G. E. Moore's discovery of the naturalistic fallacy. Unlike some of his utilitarian predecessors, Sidgwick rejected the reduction of "ought" to "is", the construction of a purely scientific morality, and the tendency to substitute psychological inquiry concerning the origins of belief for the philosophical study of their proper validity. His ethics attempted to show that commonsense morality is founded on utilitarian principles.

Several of Russell's graduate essays on ethics were assignment papers for Sidgwick's course on that topic in the Long Vacation term of 1893 and the Lent term of 1894; to a great extent, his essays then reflect Sidgwick's opinions. Russell's essay, "On Pleasure", for example, written about the same time at which he read Sidgwick's The Methods of Ethics in July 1893, claimed that even though the notion of a hedonic calculus is beset with difficulties and would necessarily be inaccurate, its practical possibility must be admitted. The evidence from the Alys letters suggests that had it not been for the decline of traditional empiricism and the critical acumen of McTaggart, Russell's utilitarian thinking might have remained intact or even been refined and expanded. As I have pointed out, McTaggart's acquaintance with Russell began with the latter's introduction to Cambridge. The acquaintance extended to friendship and influence when Russell was elected as a member of the Society (the Apostles) in February 1892. More than a year later, McTaggart put into private circulation a pamphlet entitled The Further Determination of the Absolute. ${ }^{7}$ It was his first serious piece of philosophical writing, and in it he put forward the Hegelian-inspired metaphysics to which he remained faithful throughout his career. Russell, in fact, sent Alys a copy of the pamphlet, as he did other pieces of philosophical literature, in the hope of educating her to the curious ways of philosophy. There can be no doubt that McTaggart's pamphlet created an immediate impact on Russell's thinking:

I am afraid you will find McTaggart almost unintelligible if you have never read any philosophy .... The gist is that knowledge and volition are both impossible in a state of perfection; that therefore the imperishable elements of both must be synthesized into a higher unity, love, which forms therefore the content of the absolute. The proof of this much seemed to me

" "Some Cambridge Dons of the Nineties", Portraits from Memory (London: Allen and Unwin), p. 60.

${ }^{7}$ Reprinted in Philosophical Studies, ed. S.V. Keeling (London: Arnold, 1934), pp. 210-75. 
20 Russell, nos. 29-32 (1978)

clear, but it is combined with a Hegelian philosophy which says the ideal is the real, and to that I am as yet unable to assent. (25 August 1893)

About two weeks later, after re-reading the pamphlet, he reported to Alys rather paradoxically that the crucial parts of McTaggart's reasoning were easily understandable and that, with the exception of Hegel's definition of the Absolute Idea, the difficult parts were unimportant. In view of the fact that Russell did not grasp the difficult parts, one wonders how he could have reached such a conclusion.

In comparison to the other neo-Hegelian systems in vogue at the turn of the century, McTaggart's philosophy was both unique and unorthodox. According to his interpretation of Hegel, reality is to be conceived as a harmonious community of finite souls or substances. The harmony of the community (the Absolute), he argued, necessarily presupposes that the universe is spiritual, that this spirit is immortal, mainly consists of love, is primarily good and is moving towards a state of perfection. In the pamphlet, the world's rationality and the dialectical method were both called upon to justify this idealist programme. As we have seen, Russell was favourably impressed with McTaggart's metaphysical results. This is not to say that he uncritically swallowed all of McTaggart's system. Several years later, Russell generously repaid his intellectual debt to McTaggart by stating in the dedication to An Essay on the Foundations of Geometry that the book owed its existence to McTaggart's friendship and discourse. It is important to note, however, that in his book Russell did not explicitly refer to any of McTaggart's doctrines, but resorted to certain arguments of Bradley and Bosanquet within the context of Kant's epistemology. The Alys letters reveal that prior to the philosophy espoused in his book on geometry, Russell was more sympathetically inclined to McTaggart's position; even so, such allegiance was at best qualified and critical.

The references to McTaggart and his philosophy are quite numerous in Russell's letters to Alys during 1893-94. When Alys worried about the possible loss of her independence in marriage, Russell replied that independence could not be an ideal "in the practical regulation of one's life" (19 August 1893). Independence, he contended, occupies the same position as laissez-faire in relation to socialism or, for that matter, the individual philosophy of the eighteenth century to that of the modern which views reality as a unity of spirits working towards a common goal. The "modern"
philosophy-McTaggart's-was understood by Russell to be preferable to materialism and pluralism. Another letter (9 October 1893) describes a discussion between Russell and McTaggart on the paradox that evil in the universe can be proved good. McTaggart hoped for a synthesis which would somehow resolve the incompatibility. When the subject switched to ethics, Russell elicited from McTaggart that there were two opposing points of view: the scientific, claiming that only pleasure is desirable, in contrast to the metaphysical, asserting self-realization to be the ultimate goal of conduct. It was the latter view with which Russell aligned himself when he broke away from "pure Hedonism". McTaggart's opinion was that both could be reconciled by a metaphysics which would show each implying the same conclusions. A few days later (12 October 1893), longing to see Alys, Russell complained that although metaphysics can disprove the reality of time and space "in a few strokes of the pen", it cannot alleviate the frustration of time's passage. He then added that McTaggart had given time its deathblow in Mind's October issue ("Time and the Hegelian Dialectic") but it seemed as vigorous as ever. Other mentions of, and encounters with, McTaggart include the following: McTaggart's annoyance at members of the Ethical Society such as J.H. Muirhead who substitute sentiment for proof (7 November 1893); Russell's statement that McTaggart's "views are so hopelessly mystical that only a born mystic could see any force in them" (21 November 1893); Theodore Llewelyn Davies' Society paper on socialism at which Russell got McTaggart to admit that "empirical Utilitarianism was the only method for practice, as the idealist self-realization cannot be made for directly and we don't know how to make for it" (28 January 1894). The extent to which Russell resisted McTaggart's influence can be plainly seen at another Society meeting (26 February 1894) at which Charles Sanger read a paper entitled "Which Wagner?". Sanger's talk was on art or social duty, and due to the practical nature of the topic, the ensuing discussion was hopelessly inadequate. Russell commented: "McTaggart ran his Absolute, as usual, and we protested it was useless, and if not, worked the other way ...." A new apostle, Marol, "was frightened at such an imposing machinery and was half converted to McTaggart". Russell then pointed out rather cynically: "The odd thing about the Absolute is that it always goes against the [Daily] Chronicle [a liberal newspaper], whatever that paper may say. Also that when anybody else uses it McTaggart says it can't be used."

I have stated that although Russell highly regarded McTaggart's 
work, his admiration was at the same time tempered with scepticism. While in Paris as an honorary attache at the British Embassy, he completed "Cleopatra or Maggie Tulliver", a paper for the Society on controlling the passions. According to Russell (20 October 1894, no. 83), the point of his paper was that "we can't [control our passions] and that the greater they are the less we ought to though the more easily we can"-a convoluted declaration, to say the least. In a subsequent letter to Alys (26 October 1894, no. 92), he related that the dilemma had puzzled him for a year and that its solution ultimately would require the Hegelian dialectic. He further elaborated that desire and knowledge are independent but coordinate realms "and how, just as no isolated truth is wholly true, so no isolated object of desire is wholly good". Thought, he asserted, leads to the Absolute, and similarly, desire "by alternate satisfaction and disappointment"' leads to the Absolute Good. The gulf between desire and knowledge was to be crossed somehow by passing from morality to religion. Russell however was unsure of just how the transition was to occur and was disposed to leave the problem to McTaggart. At the Society meeting at which "Cleopatra or Maggie Tulliver" was read, Russell told Alys that "McT. spoke excessively good, as I had hoped. I said in my paper I would probably accept anything he said, and so I did. For my sake he left out immortality, and reconciled my dilemma at the end without it" (4 November 1894, no. 107). On the basis of the Alys letters, we can say that McTaggart's own philosophy was only partially absorbed into Russell's thinking. He accepted McTaggart's metaphysics in its entirety only for a short period of time, perhaps two months at the most, i.e., during September and October 1893. Soon thereafter, Russell rejected the doctrine of immortality, not only in the conventional form in which a person is said to survive death, but also in McTaggart's special interpretation in which the spiritual substances of the universe are claimed to be immortal. More importantly, it would seem, Russell did not accept McTaggart's system as the final expression of Hegelianism for the simple reason that he did not fully understand it; or alternatively, because he thought that it was not capable of complete intellectual explanation. McTaggart's influence upon Russell therefore appears to have been general in nature to the extent of persuading him that Hegelianism is basically true and that, consequently, any worthwhile philosophy would have to draw its inspiration from that source.

During his trial separation from Alys at Paris, Russell acknowledged that the initial impact of McTaggart's pamphlet actually compelled him to believe in immortality: "For a few months last autumn, after reading Green and McTaggart I believed in immortality-but Green's mistakes were soon evident to me, and since then I have had no solution-I believe no other is possible" (29 October 1894, no. 96). The mention of T.H. Green in this recollection is noteworthy in view of the fact that Russell read Green's Prolegomena to Ethics about a month after he had digested McTaggart's philosophy: "I have been reading Green since I came home. I am still in the Metaphysics of Knowledge which strikes me as admirable, but so far there has been no hint of ethics" (18 September 1893). Despite its title, Green's book contains a full-scale metaphysics, and idealists viewed it as a seminal work in the development of their movement. From the fact that relations are involved with existent things, Green was led to suppose that since relations are the work of the mind, the real world must be the manifestation of mind itself (God). Based on this kind of theological idealism, his ethics emphasized the spiritual aspect of man's nature, and, in consequence, he maintained that the aim of morality is the realization of an individual's spiritual capacities. To a certain extent, Green's ethical theme is a familiar one: moral perfection is to be the criterion of conduct. F.H. Bradley's ethic of self-realization, for example, had echoed a similar sort of result but without overtones of theology or spiritualism. Russell's reaction to Green's book was as follows: "I have all but finished Green. I think it a very fine book but differ on one or two absolutely fundamental points so that I can accept very few of his conclusions tho' granted the few points where I disagree the rest seems logical enough" (25 September 1893). Russell, in fact, wrote a paper on Green for Alys' amusement and edification, entitled "On the Foundations of Ethics". The details of this paper are too complex to discuss here, but, broadly speaking, Russell argued that although Green's ideal of a universe of perfect virtue may be commendable, such an ideal at best can only provide the a priori form of morality, not its content; the content must be supplied by a metaphysical, non-ethical appeal to experience and is to be found in "ameliorated utilitarianism". His argumentation was greatly indebted to McTaggart and conceded that Green had proved Spirit to be the ultimate reality. Despite the fact that he felt his position to be "that of most of the younger men at Cambridge", he "was greatly shocked to perceive that it might also be enunciated by a broad churchman as the modern form of heaven and hell" (28 September 1893).

The material I have so far discussed in the Alys letters has concerned Russell's metaphysics and ethics in 1893-94 and the influence 
24 Russell, nos. 29-32 (1978)

of McTaggart for that period of time. The correspondence contains other important material as well. There is, for example, a marvellous description by Russell of G.E. Moore's debut at the Society (18 February 1894). According to Russell, Moore "spoke perfectly clearly and unhesitatingly" and "looked like Newton and Satan rolled into one". When Russell point out that Cambridge education had instilled a profound scepticism in the students, making them unfit for practical affairs, Moore replied in all seriousness that universal scepticism would produce a welcome result in the dissolution of society and in that way knowledge would be reconstructed empirically and better recorded. The Apostles found Moore's eloquence and sincerity so "electrifying" that they felt as if they "had all slumbered hitherto and never realized what fearless intellect pure and unadulterated really means". Given Russell's early encouragement and recognition of Moore's philosophical aptitude, it was perhaps only fitting that later on Moore would repay the service by taking the lead in their rebellion against monism and idealism.

The Alys letters also made it quite apparent that scepticism played a central role in the development of Russell's own career. His later reminiscences of his acceptance of Hegelian philosophy offer the mistaken impression that at the time he was blinded or intellectually coerced by his teachers and friends. ${ }^{8}$ This, however, simply cannot be squared with the account found in the Alys letters. He had been told by James Ward, his director of studies, "that in reading a philosophical book one should be as critical as possible and make all the objections one can" ( 25 September 1893). As he outlined it to Alys, his own method was

... to consider a question as impartially as I can for as long as it needs or as I can spare it, and then to decide as best I can, and by an act of will refuse to reconsider any decision until new facts come up. For so sceptical a nature as mine it is only by such a

${ }^{8}$ My Philosophical Development (London: Allen and Unwin, 1959), p. 11: "At Cambridge I was indoctrinated with the philosophies of Kant and Hegel ...." Russell to Michael Packe, 19 January 1954: "Mill was my philosophic god until I went to Cambridge at the age of eighteen. There they indoctrinated me with German nonsense." "My Mental Development" in P.A. Schilpp (ed.), The Philosophy of Bertrand Russell, 4th ed. (LaSalle, Ill: Open Court, 1971), p 10: "He[Stout ] and McTaggart between them caused me to become Hegelian..."." Why I 10: "He[Stout ] and Mc Taggart between them caused me to become Hegelian.... "Why 1 considerably, and I for a time fell under his sway." Autobiography, I, p. 134: ". . the bath of German idealism in which I had been plunged by Mc Taggart and Stout." "A Turning Point in My Life" in Leonard Russell (ed.), The Saturday Book, 8 (1948), p. 142: "Some have been turnings into blind alleys, as when, at the age of twenty-two, I suddenly became Hegelian ...." "My Religious Reminiscence" in R.E. Egner and L.E. Denonn (eds ) The Basic Writings of Bertrand Russell (New York: Simon and Schuster, 1961), p. 33: "McTaggart made me a Hegelian...." process that I can believe even a proposition of Euclid, much more than that one course of action is right and another wrong. (19 December 1893)

He considered his own "critical faculty" to be "very strong" and never to fail "when I have tried to exert it". At one Society meeting on "the authority of conscience apart from theology", he told Alys that "I utilized my thorough-going scepticism with regard to knowledge to show that whatever the authority of conscience, that of Euclid is no better: and everyone accepts Euclid"' (4 February 1894). He regarded himself as "a theorist, not a practical man" (3 September 1894, no. 22). When Alys' older brother, Logan, warned him not to "turn Hegelian and lose yourself in perfumed dreams" (29 October 1893), Russell assured Alys that "I don't think perfumed dreams are much in my line, at least as things to be believed in" (29 October 1893). He may have been charmed by the blissful world of philosophy ( 9 September 1804, no. 31 ), but his decision to become a Hegelian appears to have been mainly intellectual:

I fought every inch of the way against Idealism in metaphysics and Ethics-and that is why I was forced to understand it thoroughly before accepting it, and why when I came to write it out, Ward used to be enchanted by my lucidity. (22 October 1894 , no. 86)

This intellectual portait of Russell as a young enterprising philosopher is consistent with that provided by Hutchins Hapgood whom Russell met in Berlin in February 1895. The relevant quotation is to be found in Russell, no. $2 .^{9}$

Two other important topics in the Alys letters for 1893-94 are religion and politics. With her Quaker background, Alys had half hoped that Russell would be persuaded of the value of Christian belief. In return, Russell did not want to hurt Alys' feelings on the subject, but he simply could not tolerate the idea of a personal deity: "I am so utterly out of sympathy with Christianity. It would be no use at all hoping that God is a Person: no reader of metaphysics could I think be brought to such a view: it is almost as much discredited in Philosophy as circle squaring in Mathematics" (29 October 1893). Having been influenced by Green and McTaggart, he suggested that perhaps pantheism would be "a finer, a far more inspiring faith", and

${ }^{9}$ A Victorian in the Modern World (New York: Harcourt, Brace, 1939), p. 113. See also Alys to Gum (?), 16 February 1895. "Mr. H.H. [Hutchins Hapgood ] is coming to tea tomorrow. Hertie ] finds him stimulating, not because he gives out new ideas, but because he stirs B up to express his." 
that if she would read a little metaphysics, the cogency of this point of view would become more apparent. On another occasion (31 January 1894), he contended that in spite of the evil in the world, the notion of an omnipotent deity is not illogical; Russell then reasoned however that from this it would follow that God must be regarded as "an almighty fiend", neither partly good nor partly bad, because without being tempted, He had allowed evil to exist and "omnipotence cannot be tempted".

Russell's political philosophy for 1893-94 is interesting for the fact that it exhibits that same sort of uncertainty about the justification and status of political opinion as is found in his later discussions of that subject. In the presence of his Stanley relatives one night (23 August 1894), he declared himself to be a socialist, a revelation which provoked some shock in that aristocratic setting. What exactly he meant by "socialism" is not clear. Like Alys, he strongly believed in women's rights. He told her: “. . . Any improvement in the condition of the great mass of women is only possible through Socialism, and it is this discovery which has made me a Socialist" (12 September 1894). The connection of "the Woman Question with Economics" greatly enhanced his interest in social issues and he stated: “. . I should love to go into it thoroughly, historically, economically, deductively-every way it can be gone into". He had adopted an argument from Karl Pearson to the effect that the quality and survi$\mathrm{val}$ of the human race is dependent on maternity (2 October 1894, no. 60 ). Society, he argued, should therefore pay for the cost of childbearing. This would result "in a lot of Socialistic legislation", but not in "downright Collectivism", a position to which he did not adhere. It was this kind of socialism that Russell put forward in 1894, but prior to its advocacy there was considerable doubt in his mind as to its justification. He did not think it possible for socialism to be deduced from metaphysics (28 January 1894). In fact, he had written a Society paper, "Can we be Statesmen?", by which he meant "can our political opinions be determined on reasonable grounds?". $\mathrm{He}$ added: "I have come to the conclusion that it is quite impossible and I fear everyone will agree with me" (17 November 1893). His Cambridge friend, Lowes Dickinson, had invited him to participate in a discussion group on political theory (9 October 1893). Russell found the idea both "useful and interesting" since participants "would all have completely different views". With an air of frankness and paradox, he then admitted to Alys:

I have at present little notion what theoretic basis (if any) my political opinions have or can have, and I believe we shall find that political differences depend ultimately on differences of temperament which would be very satisfactory as it would put an end to the discussion.

His sceptical training at Cambridge had shown "that Reason in most things if pushed too far refutes itself" (21 November 1893).

Valuable information about Russell's philosophy can also be found in the Alys letters after 1893-94. We learn, for example (2 October 1895), that prior to receiving a Fellowship for his dissertation on non-Euclidean geometry, he wrote a philosophy exam "which contained only two questions that were not Greek or about Greek ... one from Bacon about the relation of Cause and End-the other a quotation from Kant on Space". In a discouraging meeting with Whitehead (9 October 1895), Russell was told that being "ultraempiricists", Whitehead and Ward "disagreed with almost every view I advocated in my dissertation; Ward also found my metaphysics and Psychology rather thin". Quite naturally, Russell "drew the blackest inferences" about his chances, but the next day he was elected a Fellow for six years with no teaching duties and no residence requirement. A couple of weeks later, he was visiting Oxford with Harold Joachim in hopes of seeing Bradley, whom he had enthusiastically read and admired. Despite Bradley's absence at the university, Russell's letter to Alys was a pure rhapsody of praise and devotion: "I have seen the great man's name over his door (which is just opposite Harold's), and felt the true emotion of a heroworshipper" (22 October 1895). For the years 1896-97, there is mention of Russell's first two books. By 12 September 1896, he had checked one third of the proofs of German Social Democracy, and about his revised dissertation, An Essay on the Foundations of Geometry, he told Alys: "Today I am going to the Pitt Press about my book, to the College office about my M.A., to Ward for bibliography..." (15 January 1897). In 1897, he was working on the relationship between number and quantity, the problem he considered to be the most important in mathematical philosophy. Unfortunately, the resulting paper, which appeared in Mind, July 1897, was practically unintelligible. Two references are made to it in the Alys letters. On 3 February, he admitted that he was "utterly baffled in all attempts to get on with quantity, and look[s] forward to suggestions from Whitehead. So I have set to work reading Hegel again in despair". About two months later, he wrote to Alys of the paper's reception at the Aristotelian Society:

Moore, however, despised it . . . he said I was so muddled that it 
28 Russell, nos. 29-32 (1978)

was impossible to show I was wrong, because no one could discover what I meant. We had a long argument at the Davies's afterwards in which he completely vanquished me as davies] thought it consisted merely of puns, which is what I think of Hegel. I dare say he was right, but I don't think so. (6 April 1897)

The philosophical comments in the Alys letters of 1897-1901 range over a wide area. There are numerous references to Moore as well as reports of discussions with him on kindred topics-to name a few, the reality of past time ( 8 May 1897), Moore's chance at a Fellowship (27 September 1897, 10 October and 15 November 1898), a duologue at one of Russell's papers on "whether existence means anything or not" (12 March 1898), talk concerning one of Russell's mathematical manuscripts (28 June 1898), reading Spinoza's Ethics (9 March 1899), Ward's Gifford lectures (17 October 1899), Moore's paper, "Identity" (23 October 1900), and Moore's articles in Baldwin's Dictionary of Philosophy and Psychology (14 August 1901). During that period, the Alys letters show Russell occupied with a number of philosophical endeavours. On 1 April 1898 he was reading Whitehead's Universal Algebra as background material for a new work on the foundations of mathematics. For purposes of assessment, Russell gave Lecture III of the manuscript of his book on Leibniz to Ward who in turn told him that "Leibniz was a scoundrel, that he plagiarized shamelessly" (8 March 1899). By August of 1901, Peano's logistic had become part and parcel of Russell's mathematical approach. At one of Russell's lectures on logic at Cambridge, however, a colleague, W.E. Johnson, "prepared a conundrum which he thought" Russell would be unable to explain, but according to Russell, Johnson "only displayed his own failure to understand Peano's innovations" (1 November 1901).

1902 is a significant year in the Alys letters for two reasons: first, there are more letters for that year except for the 1893-94 period, and secondly the collapse of Russell's marriage occurred sometime at the end of June and within a short time the correspondence was never quite the same-more in the nature of an exchange of notes. Suffering from severe bouts of depression, Alys had retired to Brighton for several months of rest-cure. Russell, on the other hand, had already undergone a mystical transformation in the Lent term of the previous year, and his intellectual honeymoon with mathematics had passed without solving the Contradiction. Alys, it would seem, was oblivious to the profound change in his characer. Despite constant revision and correction, The Principles of Mathematics had not been completed, and in the months of their separation Russell decided: "I cannot, in the time and present condition, finish it in style, but I can patch up something that will do for publication" (30 April 1902). The result, as he admitted to Alys, was that "the book will be full of imperfections, and will raise innumerable questions that I don't know how to answer. There is a great deal of good thinking in it, but the final product is not a work of art, as I had hoped it would be" (16 May 1902). The Alys letters of May 1902 record that in order to finish The Principles, Russell drove his intellect mercilessly, often writing a chapter a day. He went to Dunrozel (his Uncle Rollo's house at Haslemere), for example, "to tackle the most difficult chapter in the whole of my book-on the nature of classes" (8 May 1902). Even though the solution of his Contradiction was left in abeyance, his day's work on that chapter was still quite remarkable:

I did one of the hardest days of work that I have done ever in my life: seven hours real work, and two correcting proofs from Peano. I had the hardest Chapter of my book to write, and I was anxious to finish it within the day, while my mind was full of the subject. I succeeded, tho' it was thirty pages but once or twice I found myself forgetting everything in heaven and earth, as I did during my Tripos. I have been so long without real work, that I have come back to it with a kind of fever: everything else seems unreal and shadowy to me just now and I work as if I were possessed. If only I can keep it up, I shall soon get a great deal done. (9 May 1902)

Working at a frantic pace, he was tempted to use the following as a dedication to his book: "To Moloch this Altar is dedicated by a Sacred Victim" (21 May 1902). According to the Old Testament, Moloch was a Canaanite deity whose worship demanded the sacrifice of children by their parents. In a parallel way, Russell had sacrificed his ideals, work and intellect at the shrine of mathematics. By persuading himself that certain parts of his book would not have to be rewritten, he "arrived at a sudden termination" on 23 May 1902 making "only a few additions and corrections" to "a pile of old MS". After finishing the table of contents (26 May), he paused a few days or so, allowing his mind to rest, and then "full of plans of work" (12 June), he forged ahead with Volume II, reading works of previous logicians. "Formal Logic", he told Alys, "fills the crannies of my mind" (19 June). He had received "a most candid latter" from Frege ( 25 June) that "my conundrum makes not only his Arithmetic, but 
all Arithmetics, totter'. Meanwhile, Alys was returning home, partly over her depression and buoyed up with optimism and joy at the prospect of normalcy and rejuvenation in her marriage with Russell. Her hopes were soon shattered by the unrecoverable loss of his love. In despair, Russell withdrew to the cloister of mathematics, working feverishly on what became Principia Mathematica. His letter of 14 September 1902 could only offer the stoic consolation of "The Free Man's Worship":

... by deliberate courage it is possible to be happy in a kind of way whatever one's circumstances may be, and even to sympathize with the sorrows of others without losing the dignity of an internal serenity. But this is a hard doctrine, of which $I$ have only very lately learned the truth; perhaps thee will find it too hard. What it requires is resignation, the feeling Christians express by "Thy Will be done"-a feeling on which W. James has plenty to say. To me, this feeling has become part of my habitual consciousness; I hope earnestly that it may become part of thine.

As I have stated, after 1902, Russell's correspondence with Alys degenerates into a series of exchanged notes. There is some mention of his philosophical work and his collaboration with Whitehead on Principia. There are two interesting letters in 1904, for example. The first one, on 9 April, reports:

We had a great day of work, morning, afternoon and evening. Even after lunch we still worked. Much of the time we spent discussing whether the present King of France is bald-it is astonishing what intricate and remote considerations can be brought to bear on this interesting question. We finally decided that he isn't, altho' he has no hair of his own. Experienced people will infer that he wears a wig, but this would be a mistake.

Five days later, on 14 April, they even thought that the question of the King's baldness "had solved the Contradiction; but it turned out finally that the royal intellect was not quite up to that standard." The impression conveyed by the Alys letters for this period confirms Russell's statement that Principia was a joint venture and that the project was greater than either of their efforts taken singly. Again and again in the letters we find phrases which attest to the amazing amount of work accomplished by Russell and Whitehead. In one letter, he told Alys (? May 1906): "My minimum of work so far is 6 hours, my maximum 10; and my average, 9." Other pertinent philosophical matters after 1902 include: a discussion between Russell and Moore on whether there is "any difference between knowing Arithmetic and knowing one's grandmother" (26 May 1903); reports of certain papers given by Russell between 1906 and 1908; and letters in April 1908 about his attendance at the International Congress of Mathematics in Rome.

In this paper, I have presented some of the philosophical material in the Alys letters, and I hope that I have indicated its importance and abundance. Without these letters, Russell's graduate and Society essays cannot be adequately understood in the context in which they were written. Along with other correspondence for the period, we can hope to obtain a clearer picture of how his early philosophy developed.

\section{The Bertrand Russell Archives}

